\begin{tabular}{|l|l|l||}
\hline \multicolumn{2}{|c|}{ PublisherInfo } \\
\hline \hline PublisherName & $:$ & BioMed Central \\
\hline \hline PublisherLocation & $:$ & London \\
\hline \hline PublisherImprintName & $:$ & BioMed Central \\
\hline \hline
\end{tabular}

\title{
Gene may regulate need for sleep
}

\begin{tabular}{|l|l|l||}
\hline \multicolumn{2}{|c|}{ ArticleInfo } \\
\hline \hline ArticleID & $:$ & 5081 \\
\hline \hline ArticleDOI & $:$ & $10.1186 /$ gb-spotlight-20050429-01 \\
\hline \hline ArticleCitationID & $:$ & spotlight-20050429-01 \\
\hline \hline ArticleSequenceNumber & $:$ & 57 \\
\hline \hline ArticleCategory & $:$ & Research news \\
\hline ArticleFirstPage & $:$ & 1 \\
\hline \hline ArticleLastPage & $:$ & 3 \\
\hline \hline & & RegistrationDate : 2005-4-29 \\
\hline ArticleHistory & $:$ & OnlineDate \\
\hline \hline ArticleCopyright & $:$ & BioMed Central Ltd2005-4-29 \\
\hline \hline ArticleGrants & $:$ & \\
\hline \hline ArticleContext & $:$ & 130596611 \\
\hline \hline
\end{tabular}




\section{Harvey Black}

Email: hblack@chorus.net

Fruit flies carrying a single point mutation in a gene for voltage-dependent potassium channels sleep for far fewer hours each day than wildtype flies, according to research published in the April 28 issue of Nature.

Giulio Tononi and colleagues from the University of Wisconsin, Madison, examined 9000 mutant lines of Drosophila melanogasterto search for genes that might explain why some individuals manage fine on just a few hours sleep each night.

Of 15 lines that slept at least two standard deviations less than the mean each day, the researchers chose the most extreme for further examination. In this line they found a threonine-isoleucine substitution in exon 9 of the Shaker gene, a region that is very well conserved in species ranging from Drosophila to humans.

Sleep is a complex phenomenon affected by the environment and probably many genes, but some are evidently more powerful than others, coauthor Ciara Cirelli told The Scientist. "This is really the first gene that has been shown to have such a profound effect. These flies are only sleeping 3 or 4 hours instead of 10 or $12 . "$

Flies with this mutation have altered potassium channels, resulting in less hyperpolarization, or more excitability, Cirelli explained. "We feel that we are playing with a gene that is in the final common pathway of controlling sleeping because you are affecting the excitability of cell membranes."

The paper is important, "simply because we really don't know that much about genes that are involved in sleep in model organisms," commented Leslie Griffith, a biologist at Brandies University not involved in this study. "It's hard to know how important this particular gene will be, but the fact that it's possible to pick out genes and do this kind of screen will really help us get at the mechanisms [of sleep]."

"What's cool about the way they've done it is they have one tiny change in the genome, and they know exactly what it does and they can show it in a lot of different flies," said Joan Hendricks of the University of Pennsylvania, who was not involved in the study.

In examining other flies from existing stocks with the same mutation in Shaker, Tononi and colleagues ran into a surprise. "When we tested these flies for sleep, they slept normally," Cirelli said. They reasoned that because these flies carried decades-old Shakermutations, they had accumulated genetic modifiers to counterbalance the mutation.

By crossing flies with the older mutations with wild types, Cirelli and her colleagues were able to create mutant flies that were short sleepers. She reasons that the modifiers may accumulate because of selective pressure against short sleeping - the short sleeping flies have shorter life spans than normal ones. The identity of the modifiers is as-yet unclear, although the Wisconsin group is trying to map them. 
Hendricks noted that because the mutated section of the Shaker gene is so widely conserved, it could be studied in a far larger organism, such as the mouse. "If they can show it is the mutant channel in the brain that is giving them what they are looking at, that would be really cool for sleep research. That's the most burning question," she said.

\section{References}

1. J. Lucentini, "The body sleeps, but the genes do not," The Scientist, February 16, 2004., [http://www.the-scientist.com/2004/2/16/24/1]

2. C. Cirelli et al., "Reduced sleep in Drosophila Shaker mutants," Nature, 434:1087-92, April 28, 2005., [http://www.nature.com]

3. Giulio Tononi, [http://ntp.neuroscience.wisc.edu/faculty/tononi.html]

4. M.M. Stephan, "Hot Papers: Shocking disparities in voltage-dependent channels," The Scientist, December 6, 2004., [http://www.the-scientist.com/2004/12/6/22/1]

5. Chiara Cirelli, [http://ntp.neuroscience.wisc.edu/faculty/cirelli.html]

6. Leslie C. Griffith, [http://www.bio.brandeis.edu/faculty01/griffith.html]

7. Joan C. Hendricks, [http://www.med.upenn.edu/ins/faculty/hendricks.htm] 